\title{
Heart rate at discharge in patients with acute decompensated heart failure is a predictor of mortality
}

\author{
Thomas Vollmert ${ }^{1}$, Martin Hellmich², Natig Gassanov ${ }^{3}$, Fikret Er ${ }^{4}$, Seyrani Yücel ${ }^{5}$, Erland Erdmann ${ }^{1}$ \\ and Evren Caglayan ${ }^{5^{*}}$ (D)
}

\begin{abstract}
Aims: Heart failure is a syndrome with increasing prevalence in concordance with the aging population and better survival rates from myocardial infarction. Morbidity and mortality are high in chronic heart failure patients, particularly in those with hospital admission for acute decompensation. Several risk stratification tools and score systems have been established to predict mortality in chronic heart failure patients. However, identification of patients at risk with easy obtainable clinical factors that can predict mortality in acute decompensated heart failure (ADHF) are needed to optimize the care-path.
\end{abstract}

Methods and results: We retrospectively analyzed electronic medical records of 78 patients with HFrEF and HFmrEF who were hospitalized with ADHF in the Heart Center of the University Hospital Cologne in the year 2011 and discharged from the ward after successful treatment. 37.6 16.4 months after index hospitalization 30 (38.5\%) patients had died. This mortality rate correlated well with the calculated predicted survival with the Seattle Heart Failure Model (SHFM) for each individual patient. In our cohort, we identified elevated heart rate at discharge as an independent predictor for mortality $(p=0.016)$. The mean heart rate at discharge was lower in survived patients compared to patients who died $(72.5 \pm 11.9$ vs. $79.1 \pm 11.2 \mathrm{bpm}$. Heart rate of $77 \mathrm{bpm}$ or higher was associated with an almost doubled mortality risk $(p=0.015)$. Heart rate elevation of $5 \mathrm{bpm}$ was associated with an increase of mortality of $25 \%$ $(p=0.022)$.

Conclusions: Patients hospitalized for ADHF seem to have a better prognosis, when heart rate at discharge is $<77 \mathrm{bpm}$. Heart rate at discharge is an easily obtainable biomarker for risk prediction of mortality in HFrEF and HFmrEF patients treated for acute cardiac decompensation. Taking into account this parameter could be useful for guiding treatment strategies in these high-risk patients. Prospective data for validation of this biomarker and specific intervention are needed.

Keywords: Heart rate at discharge, Acute decompensated heart failure, Mortality, HFrEF, HFmrEF

*Correspondence: evren.caglayan@med.uni-rostock.de

${ }^{5}$ Department of Cardiology, University-Medicine Rostock, Rostock, Germany

Full list of author information is available at the end of the article

\section{Background}

Heart failure is a clinical syndrome with a poor prognosis and increasing prevalence [1]. Episodes with acute cardiac decompensation of chronic heart failure are associated with deterioration of left ventricular function and worsening of the clinical course [2]. An elevated resting heart rate is predictive for excessive morbidity and mortality for both men and women with and without

(c) The Author(s) 2020. This article is licensed under a Creative Commons Attribution 4.0 International License, which permits use, sharing, adaptation, distribution and reproduction in any medium or format, as long as you give appropriate credit to the original author(s) and the source, provide a link to the Creative Commons licence, and indicate if changes were made. The images or other third party material in this article are included in the article's Creative Commons licence, unless indicated otherwise in a credit line to the material. If material is not included in the article's Creative Commons licence and your intended use is not permitted by statutory regulation or exceeds the permitted use, you will need to obtain permission directly from the copyright holder. To view a copy of this licence, visit http://creativecommons.org/licenses/by/4.0/. The Creative Commons Public Domain Dedication waiver (http://creativecommons.org/publicdomain/zero/1.0/) applies to the data made available in this article, unless otherwise stated in a credit line to the data. 
cardiovascular diseases [3]. Multiple studies have confirmed this association for patients with coronary artery disease, acute myocardial infarction and heart failure [4-6].

The deleterious effects can be explained from a mechanistic point of view: an elevated heart rate leads to ischemia, abnormal calcium handling, accelerated atherosclerosis, and increased risk of plaque rupture [7]. Furthermore, an elevated resting heart rate is associated with cardiac risk factors like high systolic blood pressure, lack of physical activity, smoking and alcohol [3]. In addition, it indicates a poor cardiac function and decreased cardiorespiratory fitness.

In heart failure, an elevated heart rate preserves cardiac output in the setting of decreased stroke volume, however, this compensatory mechanism becomes maladaptive on the long term by increasing myocardial oxygen demand and reducing coronary perfusion time. Furthermore, persistent tachycardia becomes itself involved in the development of left ventricular dysfunction or heart failure, as seen in tachycardia induced cardiomyopathy [8].

In stable chronic heart failure, a slower resting heart rate is a valuable biomarker associated with a better outcome independent of left ventricular ejection fraction when patients are in sinus rhythm [9]. Therapeutically, the beneficial role of betablocker therapy in chronic heart failure patients has been addressed to reduction in heart rate, in addition to the reduction of the incidence of arrhythmias, sudden cardiac death and providing protection from ischemia [10]. Medical therapies targeting heart rate in sinus rhythm by blocking the $\mathrm{I}_{f}$ current in pacemaker cells have additionally been proven to be advantageous in reducing cardiovascular morbidity and mortality in HFrEF patients with a heart rate $\geq 70 \mathrm{bpm}$ despite optimal medical therapy in prospective multicenter studies [11, 12]. The current ESC heart failure guidelines for heart failure therefore recommend heart rate reduction with the $\mathrm{I}_{f}$ channel blocker ivabradine for symptomatic patients with chronic systolic heart failure in sinus rhythm and a heart rate of $\geq 70 \mathrm{bpm}$ as an adjunct therapeutic strategy after establishment of a treatment with a maximum tolerated dose of beta-blockers, ACE-I (or ARB) and a MRA [13]. Even a co-administration strategy of ivabradine and beta-blockers during hospital admission for acute decompensation in HFrEF patients seems to be beneficial by improving systolic function, as well as functional and clinical parameters at short term [14].

While the effect of elevated heart rate for prognosis and therapy of cardiovascular morbidity and mortality is evident in chronic heart failure, data in this regard in acute heart failure are scarce and controversial. In addition, in the clinical situation of atrial fibrillation, the association of slower heart rate and improved outcome is less clear [15]. Several studies analyzing the value of heart rate on cardiovascular outcome in the context of ADHF have obtained non-conclusive results [16-22].

In this single-center study, we sought to address the prognostic value of discharge heart rate on all-cause mortality and rehospitalization for heart failure in patients with ADHF and a reduced ejection fraction (HFrEF and HFmrEF). For this purpose, we retrospectively analyzed electronic medical records of all hospitalized patients on an all comer basis with the diagnosis of ADHF in the year 2011 who were subsequently discharged into the ambulatory care setting after successful treatment.

\section{Methods}

\section{Data collection and variables definition}

We conducted a retrospective observational study on patients with HFrEF $(n=58)$ and HFmrEF $(n=20)$ who were admitted with the diagnosis of ADHF between January 1st, 2011 and December 31st, 2011 to the Heart Center of the University of Cologne. Eligible patients for analysis were identified by screening all International Classification of Diseases codes for heart failure from electronic medical records of patients hospitalized in the department of cardiology within this time frame. Patients hospitalized with new or worsening heart failure or patients who developed significant heart failure symptoms such that HF was the primary discharge diagnosis were included. To avoid selection bias, discharge letters from individual patients were reviewed to confirm or exclude ADHF in agreement with Framingham criteria [23].

Included patients had to be older than 18 years of age, diagnosed with clinical signs and symptoms for acute decompensated heart failure, functionally classified to be in New York Heart Association class III or IV, had a left ventricular ejection fraction of $<50 \%$ on transthoracic echocardiography and hospitalized in the cardiology unit for at least $24 \mathrm{~h}$. All patients had to be successfully treated with guideline recommended heart failure treatment and discharged home after recompensation therapy.

We excluded all patients who died during the index hospitalization period. Furthermore, patients were excluded with missing echocardiography and ECG, patients with an incomplete electronic medical record and any condition likely to preclude follow-up.

Electronic medical record data were obtained from the hospital information system ORBIS ${ }^{\mathrm{TM}}$ (Agfa HealthCare Corporation), which is used for every patient treated in the University Hospital Cologne. Available data included demographic and clinical characteristics, comorbidities, previous therapies and interventions, laboratory and 
non-laboratory tests, medications and vital signs. Left ventricular ejection fraction (LVEF) was estimated with transthoracic echocardiography using Simpson's method according to current international recommendations at least once during the index hospitalization. Heart failure was categorized as being ischemic or non-ischemic in etiology depending on the presence or absence of coexisting significant coronary artery disease detected by angiography or history of previous myocardial infarction. Heart rhythm was electrocardiographically determined. Discharge heart rate and blood pressure was determined from routine measurements obtained by the responsible nurse on the ward once at the day of discharge in conformance with the local protocol for obtaining vital signs.

\section{Outcome measures}

The primary outcome was all-cause mortality. We compared clinical and laboratory characteristics of patients who survived or died until the end of the observation period. In addition, we further analyzed hospitalization for cardiovascular causes and any cause during this period. Referring to established risk score models we focused on a set of clinical and demographic factors. All data were available from clinical follow-up of the patients in the outpatient setting and obtained by electronic medical record review using ORBIS $^{\mathrm{TM}}$. Vital status was assessed from clinical follow-up in an outpatient setting in collaboration with the general practitioner/cardiologist or by direct contact with the patients to determine the overall mortality from heart failure as the primary end point of this study.

According to heart rate at discharge, patients were further evaluated in quartiles of heart rates: $<65,66-75$, $76-85$ and $>86 \mathrm{bpm}$. For further analysis, we dichotomized patients into another two groups: $\geq 77 \mathrm{bpm}$ and $<77$ beats per minute.

In addition, for validation purposes, we compared our follow-up data on mortality with the prognostic data on survival of our patients obtained from the Seattle Heart Failure Model, a reliable risk score for chronic heart failure patients [24].

The study was conducted according to the guidelines of the local ethical committee and in conformity to the principles of the Declaration of Helsinki.

\section{Statistical analysis}

Conventional descriptive statistics were used to summarize the data collected in this clinical study. For continuous variables the mean and standard deviation were used to present the data, for qualitative variables count and percentage. Kolmogorov-Smirnov test and Shapiro-Wilk test were performed to assess any deviation from normal distribution. Cox proportional hazards model were used to evaluate multivariable association with all-cause mortality. Qualitative variables were compared between groups using the chi-square test or the Fisher exact test, and quantitative variables were compared by Student's t test. The log-rank test was used to evaluate differences in all-cause mortality. A p value less than 0.05 was an indicator for statistical significance. Calculations were done with the software SPSS Statistics (IBM Corp., Armonk, NY, USA).

\section{Results \\ Study population}

From January 1st, 2011 until December 31st, 2011, 289 patients were admitted with the diagnosis ADHF to the heart center of the University Hospital Cologne for further evaluation and medical treatment (Fig. 1). From these, $n=107$ (37\%) patients were excluded: $n=24(8.3 \%)$ patients died during the index hospitalization period and $\mathrm{n}=83(28.7 \%)$ patients had heart failure with preserved ejection fraction (HFpEF) with an $\mathrm{EF} \geq 50 \%$. Furthermore, another $n=104$ (36\%) patients were lost-to-followup because of incomplete chart records $(n=95)$ and lost patient contact $(n=9)$.

\section{Clinical characteristics}

The clinical characteristics of the final study population of 78 patients who had a complete clinical follow-up are presented in Table 1 . The mean age was $69.4 \pm 13.3$ years. The majority $(78 \%$ ) of patients were male (vs. $22 \%$ female patients) and $66.7 \%$ of them were in functional class

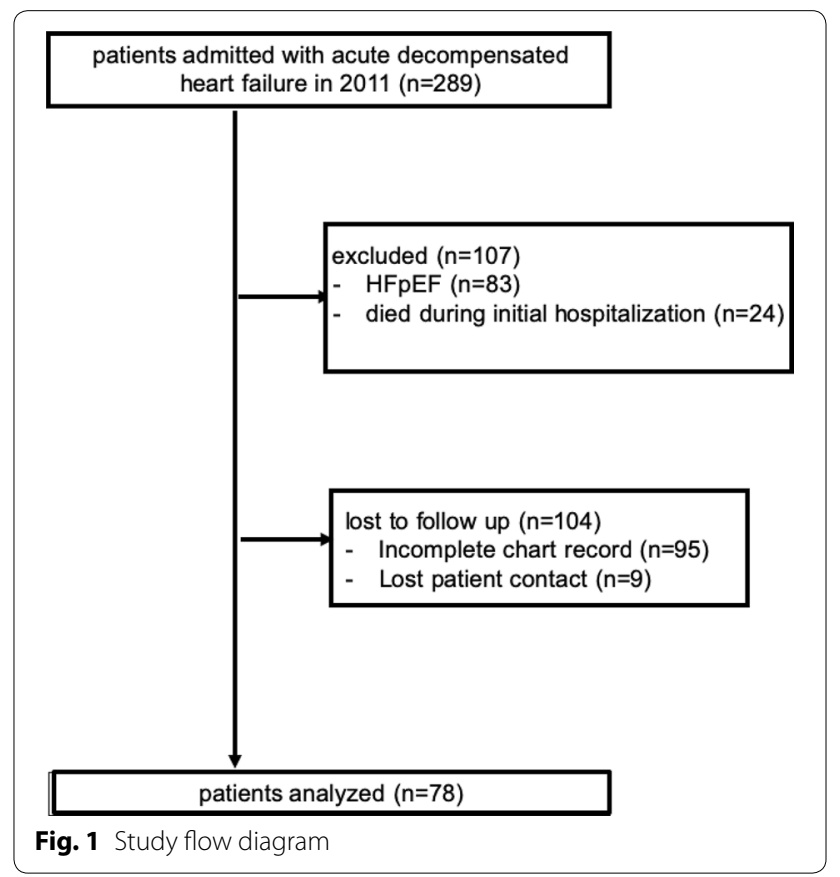


Table 1 Baseline characteristics

\begin{tabular}{|c|c|c|c|c|}
\hline Patient characteristics & all $(n=78)$ & HFrEF $(n=58)$ & HFmrEF $(n=20)$ & $p$ value \\
\hline Age (years) $\pm S D$ & $69.4 \pm 13.3$ & $68.2 \pm 13.5$ & $72.9 \pm 12.2$ & 0.176 \\
\hline Body mass index $\mathrm{kg} / \mathrm{m} 2 \pm \mathrm{SD}$ & $28.0 \pm 5.6$ & $27.9 \pm 5.5$ & $28.1 \pm 6.0$ & 0.867 \\
\hline Male / female sex (\%/\%) & $78 / 22$ & $79 / 21$ & $75 / 25$ & 0.687 \\
\hline Ejection fraction (\%) \pm SD & $31.6 \pm 9.6$ & $27.3 \pm 6.9$ & $44.0 \pm 3.2$ & $<0.001$ \\
\hline Mean heart rate $(\mathrm{bpm}) \pm \mathrm{SD}$ & $75 \pm 12$ & $76 \pm 13$ & $72 \pm 10$ & 0.184 \\
\hline Systolic blood pressure (mmHg) & $115.7 \pm 18.5$ & $111.8 \pm 15.7$ & $126.9 \pm 21.8$ & 0.001 \\
\hline \multicolumn{5}{|l|}{ NYHA functional class } \\
\hline III/IV (\%/\%) & $66.7 / 33.3$ & $66 / 34$ & $70 / 30$ & 0.714 \\
\hline \multicolumn{5}{|l|}{ Heart failure subtype } \\
\hline ICM/DCM (\%/\%) & $67.9 / 32.1$ & $66 / 34$ & $75 / 25$ & 0.433 \\
\hline \multicolumn{5}{|l|}{ Devices } \\
\hline Pacemaker (n/\%) & $17 / 21.8$ & $15 / 26.0$ & $2 / 10.0$ & \\
\hline ICD (n/\%) & $18 / 23.0$ & $16 / 28.0$ & $2 / 10.0$ & \\
\hline CRT (n/\%) & $2 / 2.6$ & $2 / 3.4$ & $0 / 0$ & \\
\hline \multicolumn{5}{|l|}{ Comorbidities } \\
\hline Atrial fibrillation (n/\%) & $34 / 43.6$ & $23 / 39.7$ & $11 / 55.0$ & 0.142 \\
\hline Diabetes mellitus (n/\%) & $33 / 42.3$ & $24 / 41.4$ & $9 / 45.0$ & 0.926 \\
\hline Arterial Hypertension (n/\%) & $59 / 75.6$ & $43 / 74.1$ & $16 / 80.0$ & 0.598 \\
\hline Hyperlipoproteinemia (n/\%) & $45 / 57.7$ & $35 / 60.3$ & $10 / 50$ & 0.419 \\
\hline Chronic renal failure (GFR $\leq 60 \mathrm{ml} / \mathrm{min})(\mathrm{n} / \%)$ & $16 / 20.5$ & $14 / 24.1$ & $2 / 10$ & 0.070 \\
\hline Chronic obstructive pulmonary disease (n/\%) & 18/23.1 & $12 / 20.7$ & $6 / 30.0$ & 0.394 \\
\hline Current smoker (n/\%) & $30 / 38.5$ & $23 / 39.7$ & $7 / 35.0$ & 0.904 \\
\hline \multicolumn{5}{|l|}{ Laboratory values } \\
\hline Haemoglobin $(\mathrm{g} / \mathrm{dl}) \pm \mathrm{SD}$ & $13.2 \pm 1.9$ & $13.3 \pm 1.9$ & $12.8 \pm 2.0$ & 0.295 \\
\hline Serum sodium $(\mathrm{mmol} / \mathrm{l}) \pm \mathrm{SD}$ & $138.9 \pm 4.1$ & $139.0 \pm 4.1$ & $138.7 \pm 4.6$ & 0.734 \\
\hline Cholesterine $(\mathrm{mg} / \mathrm{dl}) \pm \mathrm{SD}$ & $162.9 \pm 41.7$ & $165.2 \pm 45.1$ & $156.3 \pm 40.0$ & 0.432 \\
\hline Serum creatinine $(\mathrm{mg} / \mathrm{dl}) \pm \mathrm{SD}$ & $1.45 \pm 0.8$ & $1.45 \pm 0.7$ & $1.44 \pm 1.2$ & 0.948 \\
\hline Blood urea nitrogen $(\mathrm{mg} / \mathrm{dl}) \pm S D$ & $72.7 \pm 41.2$ & $73.0 \pm 41.0$ & $71.8 \pm 42.7$ & 0.909 \\
\hline NTpro-BNP (pg/ml) & $6823 \pm 9824$ & $7285 \pm 10024$ & $352 \pm 0$ & 0.516 \\
\hline \multicolumn{5}{|l|}{ Medication } \\
\hline ACE inhibitor or ARB (\%) & 82.1 & 84.5 & 75 & 0.669 \\
\hline Beta-blocker (\%) & 91 & 91.4 & 90 & 0.813 \\
\hline Aldosterone antagonist (\%) & 65.4 & 72.4 & 45 & 0.120 \\
\hline Calcium antagonists (\%) & 10.3 & 3.4 & 30 & 0.030 \\
\hline Diuretics (\%) & 91 & 96.6 & 75 & 0.117 \\
\hline Digitalis glycosides (\%) & 28.2 & 29.3 & 25 & 0.200 \\
\hline Amiodarone (\%) & 9 & 12.1 & 0 & 0.103 \\
\hline Anticoagulant therapy (\%) & 33.3 & 31 & 40 & 0.220 \\
\hline Antiplatelet therapy (\%) & 48.7 & 44.8 & 60 & 0.192 \\
\hline Lipid lowering therapy (\%) & 50 & 50 & 50 & 0.762 \\
\hline Xantine oxidase inihibitors (\%) & 21.8 & 24.1 & 15 & 0.520 \\
\hline
\end{tabular}

NYHA III (vs. 33.3\% NYHA IV patients). The mean ejection fraction determined by echocardiography was $31.6 \pm 9.6 \%$. Heart failure was in $67.9 \%$ of ischemic origin and in $32.1 \%$ dilative. The mean resting heart rate at discharge was $75.0 \pm 12.0 \mathrm{bpm}$ [CI 72.3; $77.7 \mathrm{bpm}$ ] with a normal distribution.
All patients received guideline directed medical therapy at discharge to the maximally tolerated dosage. ACE inhibitors or Angiotensin Receptor Blockers were taken by $84.6 \%$, beta-blockers by $92.3 \%$ and mineralocorticoid receptor antagonists even by $65.4 \%$ of the study cohort. 
$23 \%$ of patients had an ICD as primary or secondary prevention, but only $3 \%$ had cardiac resynchronization therapy. The most prevalent comorbidity was arterial hypertension (75.6\%), followed by hyperlipoproteinemia (57.7\%), atrial fibrillation (43.6\%) and diabetes mellitus (42.3\%). Chronic renal failure with an estimated GFR of less than $60 \mathrm{ml} / \mathrm{min}$ was evident in $20.5 \%$ of all studied patients. Smoking habits were common with $38.5 \%$ current smokers. The mean NT-proBNP was $6823 \pm 9824 \mathrm{ng} / \mathrm{L}$.

We further performed an analysis on the different characteristics of HFrEF and HFmrEF patients in the study. HFmrEF patients had a significantly higher blood pressure at discharge and were significantly taking more calcium antagonists in their medication.

\section{Predictors of mortality}

After a mean follow-up of $37.6 \pm 16.4$ months, 30 (38.5\%) patients died (Table 2). Their mean survival time was 1.87 years [CI 1.46; 2.27 years]. Heart rate at discharge was a significant predictor of mortality $(p=0.016$, Pearson $r=0.28$ ), besides known prognostic parameters like systolic blood pressure $(p=0.004)$, NYHA functional class IV $(p=0.048)$, hemoglobin $(p=0.009)$, serum creatinine $(p=0.002)$ and blood urea nitrogen $(p<0.001)$. Medication of xanthine oxidase inhibitors was associated with elevated mortality $(P=0.015)$.

Besides these significant variables, we could detect a tendency in terms of clinical and laboratory features that patients who survived were younger in age with a higher, slightly overweight BMI, with a better ejection fraction and renal function and less often have atrial fibrillation and diabetes mellitus as comorbidities.

When HFrEF and HFmrEF patients were compared separately, heart rate, NYHA class, serum creatinine, BUN and intake of xanthine oxidase inhibitors were significantly predictive for mortality in HFrEF patients, whereas BMI, systolic blood pressure, the presence of atrial fibrillation and low hemoglobin levels were predictive for mortality in HFmrEF patients.

\section{The role of heart rate at discharge}

The mean heart rate of patients who survived was $72.5 \pm 11.9 \mathrm{bpm}$ [CI 69.0; $75.9 \mathrm{bpm}$ ] compared to $79.1 \pm 11.2 \mathrm{bpm}$ [CI 74.9; $83.3 \mathrm{bpm}$ ] of patients who died during the study period. Furthermore, heart rate at discharge correlated significantly with mortality $(r=0.28$, $p=0.013)$. Looking at the quartiles of heart rates at discharge, we observed an increasing mortality with higher heart rates at discharge. The 4 year mortality rates for the quartiles analyzed were as follows: $<65 \mathrm{bpm}: 16.7 \%$, 66-75 bpm: $40.9 \%, 76-85$ bpm: $42.3 \%$ and $>86$ bpm: $58.3 \%$.
Mortality rate at 4 years follow-up was nearly doubled $(54.8 \%$ vs. $27.7 \%)$, when patients were dichotomized to a heart rate at discharge of greater or equal than 77-112 bpm compared to patients with a heart rate of 40-76 bpm (Fig. 2). This is also shown in the survival analysis using Kaplan-Meier estimate with a significantly better survival of patients with a heart rate at discharge of $\geq 77 \mathrm{bpm}(p=0.028)$ (Fig. 3).

We observed a linear relationship between mortality and heart rate at discharge with increasing odds for death by $5 \%$ with every heart beat per minute rising from baseline rate $(p=0.022)$.

We could not detect a significant correlation between discharge heart rate and readmission for heart failure or any other cause. Furthermore, we could not detect significant differences in the prediction of mortality due to heart rate at discharge whether patients were in sinus rhythm or had atrial fibrillation. Although patients with atrial fibrillation tended to have a worse prognosis per se (Table 2).

Finally, to exclude bias due to hospital factors, we calculated the survival of each individual patient using the Seattle Heart Failure Model (SHFM) with the individual patient data available at discharge and compared the predicted survival curve to the actual survival of the cohort. Hereby, we could confirm that the effective survival curve was similar to the predicted by the SHFM, suggesting that the calculated factors in the investigated cohort were representative to a similar sick cohort in a bigger heart failure population (Fig. 4).

\section{Discussion}

In this clinical investigation, we were able to demonstrate that heart rate at discharge is a predictor of mortality in patients with HFrEF and HFmrEF discharged to ambulatory care after an episode with ADHF. A heart rate $\geq 77 \mathrm{bpm}$ was associated with a nearly twofold increased mortality in this patient population. We could not detect differences for the role of this parameter in regard to the existing cardiac rhythm at discharge. In addition, this parameter was not predictive for rehospitalization.

The prognostic impact of heart rate in ADHF is still a matter of debate. In contrast to the predictive role of this biomarker in chronic systolic heart failure the role of heart rate in ADHF is much more controversial. This is partly due to differences in the time point when heart rate was measured during an acute decompensation period and focusing on different end points like in-hospital mortality and readmission in various studies [16-22].

Risk of in-hospital mortality and particularly mortality and rehospitalization for patients hospitalized with ADHF remains high [25]. It is increased in patients 
Table 2 Characteristics of survivors vs. deaths

\begin{tabular}{|c|c|c|c|c|c|c|c|c|c|}
\hline \multirow[t]{2}{*}{$\begin{array}{l}\text { Patient } \\
\text { characteristics }\end{array}$} & All $(n=78)$ & $\begin{array}{l}\text { Alive } \\
(n=48 / 62 \%)\end{array}$ & $p$ value & HFrEF $(n=58)$ & $\begin{array}{l}\text { Alive } \\
(n=34 / 59 \%)\end{array}$ & $p$ value & $\begin{array}{l}\text { HFmrEF } \\
(n=20)\end{array}$ & $\begin{array}{l}\text { Alive } \\
(n=14 / 70 \%)\end{array}$ & \multirow[t]{2}{*}{$p$ value } \\
\hline & \multicolumn{3}{|l|}{$\begin{array}{l}\text { Dead } \\
(n=30 / 38 \%)\end{array}$} & \multicolumn{3}{|l|}{$\begin{array}{l}\text { Dead } \\
(n=24 / 41 \%)\end{array}$} & \multicolumn{2}{|l|}{$\begin{array}{l}\text { Dead } \\
(n=6 / 30 \%)\end{array}$} & \\
\hline $\begin{array}{l}\text { Age (years) } \\
\quad \pm \mathrm{SD}\end{array}$ & $70.8 \pm 13.7$ & $68.6 \pm 13.1$ & 0.472 & $68.7 \pm 14.2$ & $67.9 \pm 13.2$ & 0.826 & $79.2 \pm 7.1$ & $70.2 \pm 13.1$ & 0.136 \\
\hline $\begin{array}{l}\text { Body mass } \\
\text { index } \mathrm{kg} / \mathrm{m} 2 \\
\pm \mathrm{SD}\end{array}$ & $26.7 \pm 6.6$ & $28.7 \pm 4.7$ & 0.13 & $27.7 \pm 6.8$ & $28.1 \pm 4.4$ & 0.809 & $23.1 \pm 4.7$ & $30.3 \pm 5.2$ & 0.009 \\
\hline $\begin{array}{c}\text { Male/female } \\
\text { sex }(\% / \%)\end{array}$ & $77 / 23$ & $79 / 21$ & 0.79 & $83 / 17$ & $76 / 24$ & 0.525 & $50 / 50$ & $86 / 14$ & 0.091 \\
\hline $\begin{array}{l}\text { Ejection frac- } \\
\quad \text { tion }(\%) \pm S D\end{array}$ & $29.5 \pm 10.8$ & $32.9 \pm 8.6$ & 0.127 & $25.5 \pm 8.0$ & $28.5 \pm 5.9$ & 0.101 & $45.3 \pm 3.0$ & $43.4 \pm 3.2$ & 0.231 \\
\hline $\begin{array}{l}\text { Mean heart rate } \\
\quad(\mathrm{bpm}) \pm \mathrm{SD}\end{array}$ & $79.1 \pm 11.2$ & $72.5 \pm 11.9$ & 0.016 & $80.1 \pm 11.7$ & $73.3 \pm 12.7$ & 0.041 & $75.2 \pm 8.9$ & $70.6 \pm 9.8$ & 0.339 \\
\hline $\begin{array}{l}\text { Systolic blood } \\
\text { pressure } \\
\text { (mmhg) }\end{array}$ & $108.2 \pm 16.3$ & $120.4 \pm 18.4$ & 0.004 & $108.5 \pm 16.7$ & $114.2 \pm 14.7$ & 0.173 & $107.2 \pm 16.1$ & $135.4 \pm 18.3$ & 0.004 \\
\hline \multicolumn{10}{|c|}{ NYHA functional class } \\
\hline III/IV (\%) & $53 / 47$ & $75 / 25$ & 0.048 & $50 / 50$ & $76 / 24$ & 0.037 & $67 / 33$ & $71 / 29$ & 0.831 \\
\hline \multicolumn{10}{|l|}{ Comorbidities } \\
\hline $\begin{array}{l}\text { Atrial fibrilla- } \\
\text { tion (\%) }\end{array}$ & 57 & 35 & 0.107 & 46 & 35 & 0.419 & 100 & 36 & 0.014 \\
\hline $\begin{array}{l}\text { Diabetes mel- } \\
\text { litus (\%) }\end{array}$ & 53 & 35 & 0.055 & 54 & 32 & 0.071 & 50 & 57 & 0.621 \\
\hline $\begin{array}{c}\text { Arterial hyper- } \\
\text { tension (\%) }\end{array}$ & 73 & 77 & 0.707 & 71 & 76 & 0.629 & 83 & 79 & 0.807 \\
\hline $\begin{array}{l}\text { Hyperlipopro- } \\
\text { teinemia (\%) }\end{array}$ & 57 & 58 & 0.885 & 58 & 62 & 0.792 & 50 & 50 & 1.000 \\
\hline $\begin{array}{c}\text { Chronic renal } \\
\text { failure (gfr } \leq \\
60 \mathrm{ml} / \mathrm{min} \text { ) }\end{array}$ & 33 & 13 & 0.05 & 38 & 15 & 0.069 & 17 & 7 & 0.515 \\
\hline $\begin{array}{l}\text { Chronic } \\
\text { obstructive } \\
\text { pulmonary } \\
\text { disease (\%) }\end{array}$ & 30 & 19 & 0.251 & 25 & 18 & 0.496 & 50 & 21 & 0.201 \\
\hline $\begin{array}{l}\text { Current } \\
\text { smoker }\end{array}$ & 33 & 42 & 0.728 & 38 & 41 & 0.94 & 17 & 50 & 0.362 \\
\hline \multicolumn{10}{|l|}{ Laboratory values } \\
\hline $\begin{array}{l}\text { Haemoglobin } \\
\qquad(\mathrm{g} / \mathrm{dl}) \pm S D\end{array}$ & $12.5 \pm 2.1$ & $13.7 \pm 1.7$ & 0.009 & $12.8 \pm 2.0$ & $13.8 \pm 1.7$ & 0.060 & $11.4 \pm 1.9$ & $13.5 \pm 1.8$ & 0.027 \\
\hline $\begin{array}{l}\text { Serum } \\
\quad \text { sodium } \\
\text { (mmol/l) } \\
\pm \mathrm{SD}\end{array}$ & $138.0 \pm 4.9$ & $139.4 \pm 3.4$ & 0.125 & $138.5 \pm 4.4$ & $139.3 \pm 3.8$ & 0.429 & $136.0 \pm 6.7$ & $139.7 \pm 2.4$ & 0.239 \\
\hline $\begin{array}{l}\text { Cholesterine } \\
(\mathrm{mg} / \mathrm{dl}) \pm \\
\mathrm{SD}\end{array}$ & $155.4 \pm 38.3$ & $167.5 \pm 46.0$ & 0.231 & $159.7 \pm 40.4$ & $169.0 \pm 49.4$ & 0.441 & $138.3 \pm 23.7$ & $163.9 \pm 41.0$ & 0.174 \\
\hline $\begin{array}{l}\text { Serum creati- } \\
\text { nine }(\mathrm{mg} / \mathrm{dl}) \\
\quad \pm \mathrm{SD}\end{array}$ & $1.82 \pm 1.19$ & $1.22 \pm 0.38$ & 0.002 & $1.77 \pm 0.86$ & $1.23 \pm 0.37$ & 0.008 & $2.03 \pm 2.18$ & $1.19 \pm 0.43$ & 0.390 \\
\hline $\begin{array}{l}\text { Blood urea } \\
\text { nitrogen } \\
(\mathrm{mg} / \mathrm{dl}) \pm \\
\text { SD }\end{array}$ & $93.9 \pm 54.1$ & $59.4 \pm 22.4$ & $<0.001$ & $92.5 \pm 54.6$ & $59.2 \pm 19.0$ & 0.008 & $99.7 \pm 57.0$ & $59.8 \pm 30.1$ & 0.053 \\
\hline Ntpro-bnp & $11731 \pm 15582$ & $6823 \pm 9824$ & 0.18 & $11731 \pm 15582$ & $4815 \pm 4760$ & 0.23 & n.a. & 352 & n.a. \\
\hline \multicolumn{10}{|l|}{ Medication } \\
\hline $\begin{array}{c}\text { Ace inhibitor } \\
\text { or ARB (\%) }\end{array}$ & 70 & 90 & 0.13 & 79 & 88 & 0.166 & 33 & 93 & 0.122 \\
\hline
\end{tabular}


Table 2 (continued)

\begin{tabular}{|c|c|c|c|c|c|c|c|c|c|}
\hline \multirow[t]{2}{*}{$\begin{array}{l}\text { Patient } \\
\text { characteristics }\end{array}$} & All $(n=78)$ & $\begin{array}{l}\text { Alive } \\
(n=48 / 62 \%)\end{array}$ & $p$ value & HFrEF $(n=58)$ & $\begin{array}{l}\text { Alive } \\
(n=34 / 59 \%)\end{array}$ & $p$ value & $\begin{array}{l}\text { HFmrEF } \\
(n=20)\end{array}$ & $\begin{array}{l}\text { Alive } \\
(n=14 / 70 \%)\end{array}$ & \multirow[t]{2}{*}{$p$ value } \\
\hline & $\begin{array}{l}\text { Dead } \\
(n=30 / 38 \%)\end{array}$ & & & $\begin{array}{l}\text { Dead } \\
(n=24 / 41 \%)\end{array}$ & & & $\begin{array}{l}\text { Dead } \\
(n=6 / 30 \%)\end{array}$ & & \\
\hline $\begin{array}{l}\text { Betablocker } \\
(\%)\end{array}$ & 90 & 92 & 0.664 & 92 & 91 & 0.738 & 83 & 93 & 0.281 \\
\hline $\begin{array}{l}\text { Aldosterone } \\
\text { antagonist } \\
(\%)\end{array}$ & 57 & 71 & 0.374 & 58 & 82 & 0.281 & 50 & 43 & 0.419 \\
\hline $\begin{array}{l}\text { Calcium } \\
\text { antagonists } \\
(\%)\end{array}$ & 0 & 17 & 0.062 & 0 & 6 & 0.481 & 0 & 43 & 0.159 \\
\hline Diuretics (\%) & 90 & 92 & 0.506 & 96 & 97 & 0.456 & 67 & 79 & 0.614 \\
\hline $\begin{array}{l}\text { Digitalis gly- } \\
\text { coside (\%) }\end{array}$ & 33 & 25 & 0.458 & 33 & 26 & 0.496 & 33 & 21 & 0.414 \\
\hline $\begin{array}{l}\text { Amiodarone } \\
(\%)\end{array}$ & 13 & 6 & 0.287 & 17 & 9 & 0.366 & 0 & 0 & n.a. \\
\hline $\begin{array}{l}\text { Lipid lowering } \\
\text { therapy (\%) }\end{array}$ & 53 & 48 & 0.652 & 50 & 50 & 1 & 67 & 43 & 0.11 \\
\hline $\begin{array}{l}\text { Xantine } \\
\text { oxidase } \\
\text { inihibitors } \\
(\%)\end{array}$ & 40 & 10 & 0.015 & 46 & 9 & 0.013 & 17 & 14 & 0.203 \\
\hline
\end{tabular}

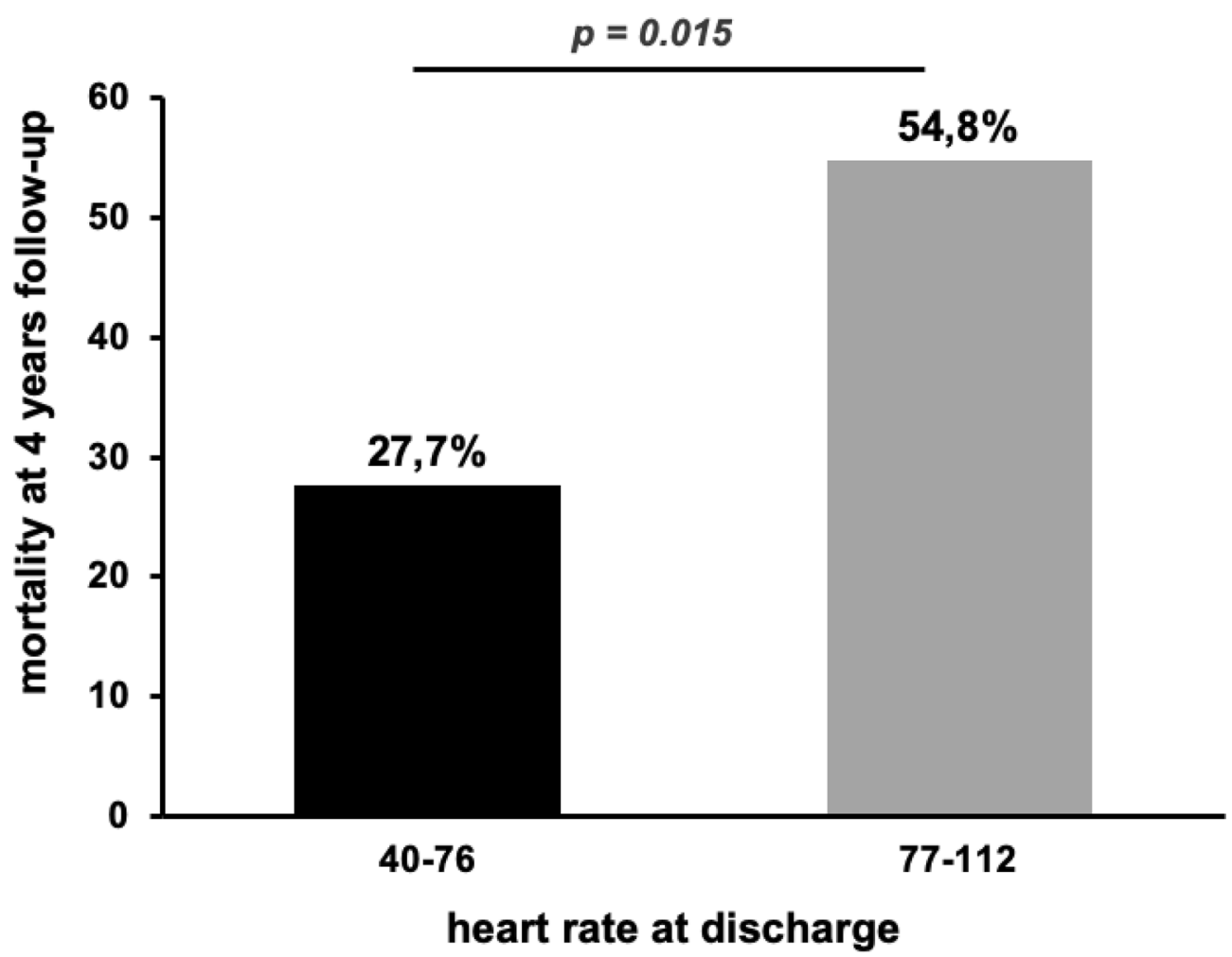

Fig. 2 Mortality rates at 4 years follow-up in patients dichotomized to heart rates 40-76 and 77-120 bpm 


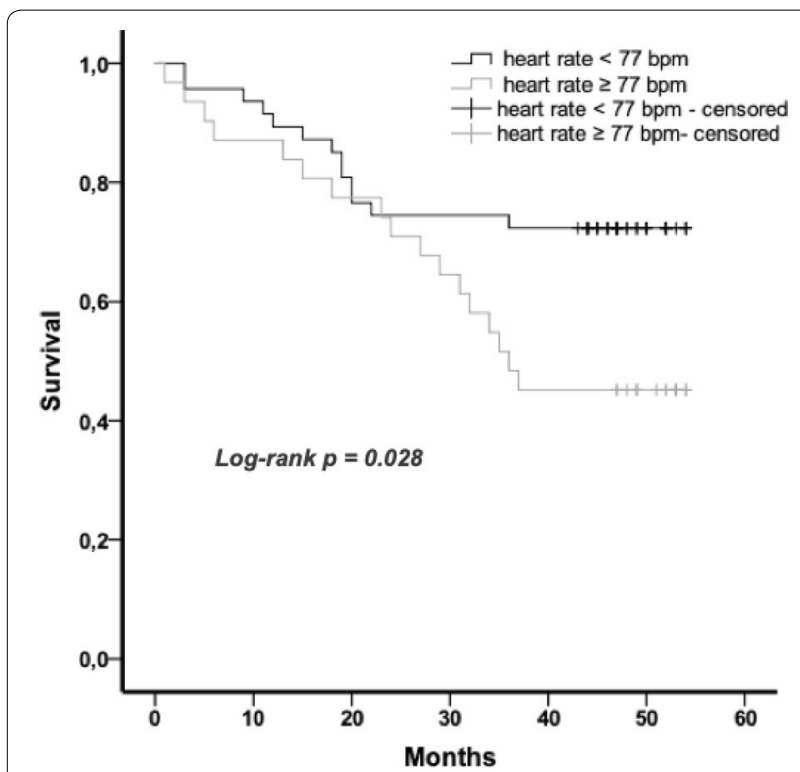

Fig. 3 Kaplan-Meier survival curves of patients with a discharge heart rate $\geq 77$ and $<77$ bpm

with impaired metabolic status, neurohormonal activation and reduced cardiac performance, gauged by BUN, serum albumin and cholesterol levels, systolic blood pressure, heart rate, and respiratory rate [26]. Particularly, admission heart rate has been shown to be an independent risk factor for mortality during the acute phase as well as in the long term. A higher heart rate on admission was independently associated in a J-shape relationship with higher in-hospital mortality in ADHF patients with the lowest mortality seen at heart rates of 70-75 bpm [16]. Furthermore, a higher heart rate at presentation in the emergency department with ADHF was associated with an increased 7 day mortality [27]. On the other hand, higher admission heart rate can also predict survival advantage in acute HF and improve left ventricular reverse remodeling $[19,28]$. However, lower heart rate is also a marker for increased in-hospital mortality in ADHF, suggesting the existence of an ideal heart rate window in these patients [18].

Some studies have correlated the difference between admission and discharge heart rate to hard cardiovascular end points [20]. Patients presenting with tachycardia and discharged with a controlled heart rate were shown to have a better outcome than those admitted non-tachycardic or discharged with a non-controlled heart rate [19]. These observations are explained by the hypothesis that elevated heart rate in the initial period of ADHF may be an indicator of preserved cardiac reserve and chronotropic competence, as the ability of the cardiovascular system to respond to this extraordinary stress situation with an adrenergic burst is preserved. Hence, heart rate recovery indicates a functioning vagal arm of the autonomous nervous system resulting in a better prognosis in patients with systolic heart failure. Nevertheless, both admission heart rate as well as heart rate difference

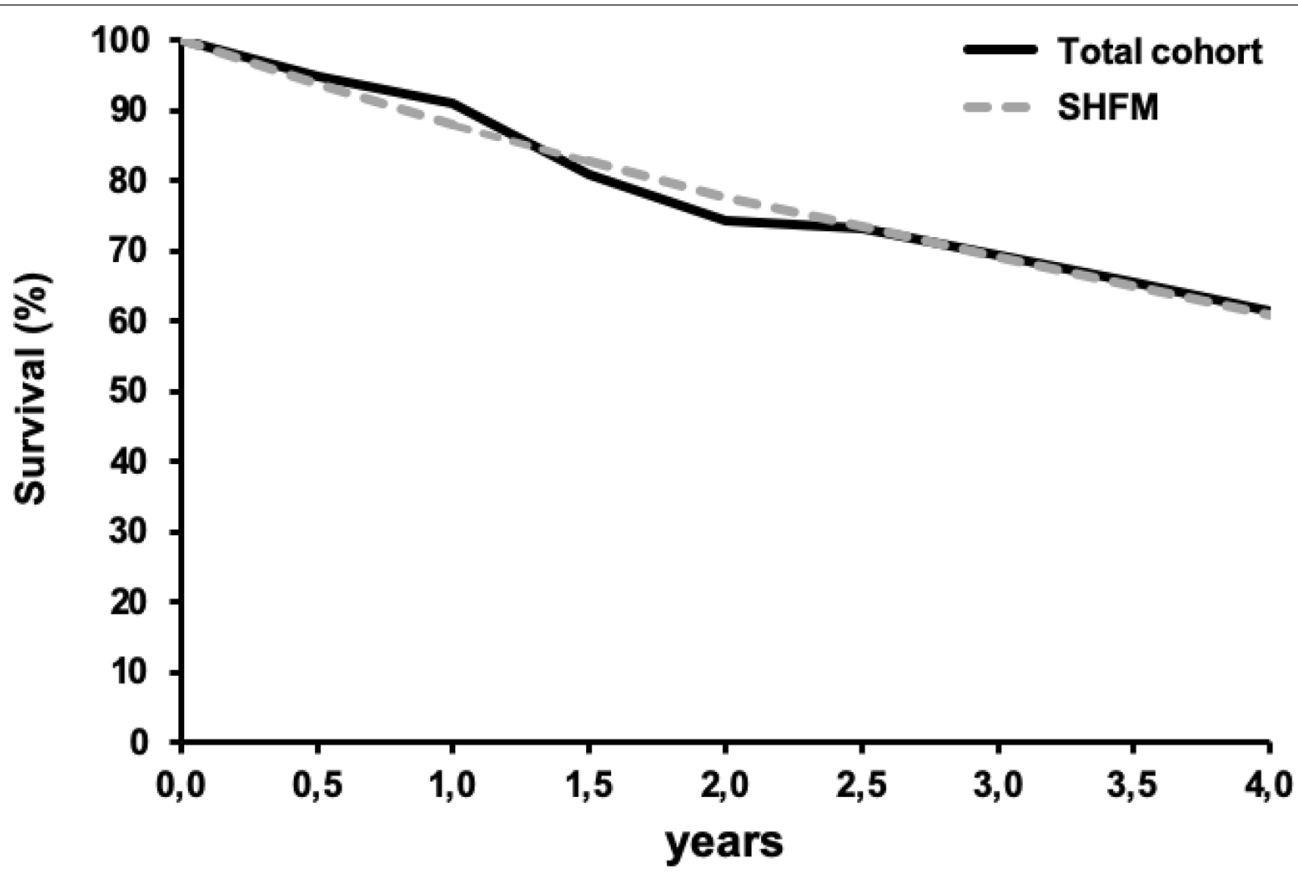

Fig. 4 Kaplan-Meier actual survival curves of the study cohort compared with the survival curves calculated with the SHFM 
(admission-discharge heart rate) are complicated to introduce into routine clinic algorithms for risk prediction in ADHF.

A variety of short- and long-term mortality predictors have been analyzed in patients with ADHF. Nevertheless, application of a sophisticated risk-prediction algorithm to identify patients at high risk for mortality who might benefit from aggressive monitoring and intervention using various variables suggested in the Organized Program to Initiate Lifesaving Treatment In Hospitalized Patients With Heart Failure (OPTIMIZE-HF) trial are even more cumbersome to perform in routine clinical practice $[17,25,26]$.

Only few studies like ours have concentrated on heart rate at discharge for risk prediction. This parameter has several advantages: it is easy and reliably to determine, routinely available and reflects the most stable condition the patient is able to achieve and therefore may be much more relevant for the future course. Indeed, an elevated discharge heart rate is independently associated with a poor prognosis in patients revascularized with percutaneous coronary intervention for stable angina or acute coronary syndromes as well as after acute myocardial infarction [21, 29].

Our results are in line with a big retrospective cohort study of registry data showing that a higher discharge heart rate after treatment for ADHF in unselected heart failure patients is associated with an increased risk of death and rehospitalization with an even higher risk in the first 30 days after discharge [30].

The strength of our study is a high percentage of patients with guideline-based medical and device therapy and the unique long-term follow-up period with a mean duration of more than 3 years. Besides that, compared to previous studies we focused on patients with primarily systolic heart failure with an ejection fraction $<50 \%$. The population analyzed ended up with a sicker cohort of HFrEF and HFmrEF patients with a more severely reduced mean EF. Probably due to the nearly optimal guideline directed medical therapy and the younger mean age of our study cohort, the mortality rates were noticeably lower compared to previously published studies. However, observed survival rates similar to predicted survival rates calculated with the SHFM were confirmative to exclude selection bias.

Particular differences in the study cohort might account for the differences observed in the mortality rates. In contrast to our study, the population investigated by Laskey et al. included patients who were nearly a decade older (median age 80 years) with systolic and diastolic heart failure. They had a more preserved LVEF (median 45\%). In addition, this cohort included fewer ICD patients, more women and less patients with heart failure due to ischemic origin. Lastly, the followup period in this analysis was only 12 months. Overall, both studies underscore the positive association between discharge heart rate and mortality in patients with heart failure.

While this association is true for patients in sinus rhythm, the data in regard to Afib patients are less clear. Atrial fibrillation is not only independently associated with adverse prognosis in chronic but also in acute heart failure at least up to 1 year post-discharge [31]. Only few studies have analyzed the relationship between heart rate and mortality in ADHF patients with atrial fibrillation thereby obtaining divergent results $[22,30]$. In our study, we could not detect a difference in the association of heart rate at discharge and mortality between patients presenting in SR versus those with Afib, although there was tendency that Afib was more prevalent in patients who died $(p=0.107$; Table 2). A recent meta-analysis of randomized controlled trials suggests that in regard to mortality a lower heart rate in stable HFrEF patients is associated with a better prognosis only when patients were in sinus rhythm, while this association was not seen in Afib patients [32].

The optimum heart rate at discharge in respect to mortality risk for heart failure patients is not clear. We performed an exploratory analysis of the heart ratemortality association to determine a cut-off heart rate with incremental hazard. From previous and our investigation there seems to be an upper cut-off window of $75-76 \mathrm{bpm}$. When the resting heart rate is above this rate, mortality seems to increase disproportionately. This upper cut-off window might be higher in Afib patients, although we were not able to detect significant differences in our study due to the small sample size and supposedly higher heart rate variability during Afib.

Lastly, in regard to the observed significantly higher mortality in patients taking xanthine oxidase inhibitors, indeed, in a recent systematic review and meta-analysis of uric acid-lowering agents on cardiovascular outcome in patients with heart failure treatments, allopurinol treatment was associated with a significant increase in the risk for all-cause and cardiovascular mortality [33]. Whether the observed effect of an increased mortality in patients treated with a xanthine oxidase inhibitor in our study is due to a treatment effect or elevated uric acid levels leading to medical treatment characterizes a sicker heart failure population cannot be answered with the data presented. Xanthine oxidase inhibition with allopurinol has not been demonstrated to show additional benefit nor harm in high-risk HFrEF patients with elevated uric acid levels [34]. 


\section{Limitations}

There are a few limitations of this study. This is a singlecenter retrospective analysis without having access to structured registry data. Hospital factors and a rather high number of patients who had to be excluded due to incomplete chart record might have influenced the results. In addition, we had to rely on the accuracy of documentation. It cannot be fully ruled out that physiologic variables may not have been accurately recorded or been subjected to rounding which could have influenced the results. Furthermore, not all possible prognostic parameters were available in the dataset. Residual measured and unmeasured confounding factors may influence the results. Nevertheless, a considerable number of events were analyzed and we tried to exclude bias considering every patient with the diagnosis of ADHF in our study.

\section{Conclusions}

Taking into account heart rate at discharge in patients with ADHF and systolic heart failure may allow for greater discrimination of the highest risk patients. Further investigation should address whether heart rate reduction could be a therapeutic strategy in ADHF.

\section{Acknowledgements}

None

\section{Authors' contributions}

TV collected and analyzed the data and deigned the figures, M.H. performed the statistical analysis; NG, SY, FE; EE substantially contributed to the interpretation of the data and revised the manuscript; EC designed the study and wrote the manuscript with input from all authors. All authors discussed the results and contributed to the final manuscript. All authors read and approved the final manuscript.

\section{Funding}

The authors received no financial support for the research, authorship, and/or publication of this article.

\section{Availability of data and materials}

All original data supporting the findings of the study are available from the corresponding author on request.

\section{Ethics approval and consent to participate}

Not applicable.

\section{Consent for publication}

All named authors have seen and approved the final version of the manuscript and agree with its submission to European Journal of Medical Research.

\section{Competing interests}

The authors declare that there is no conflict of interest.

\section{Author details}

${ }^{1}$ Department III for Internal Medicine, University of Cologne, Cologne, Germany. ${ }^{2}$ Institute of Medical Statistics and Computational Biology (IMSB), Faculty of Medicine and University Hospital Cologne, University of Cologne, Cologne, Germany. ${ }^{3}$ Department II for Internal Medicine, Klinikum Idar-Oberstein, Idar-Oberstein, Germany. ${ }^{4}$ Department of Cardiology and Electrophysiology, Klinikum Gütersloh, Gütersloh, Germany. ${ }^{5}$ Department of Cardiology, University-Medicine Rostock, Rostock, Germany.

Received: 19 August 2020 Accepted: 26 September 2020

Published online: 08 October 2020

\section{References}

1. Savarese G, Lund LH. Global Public Health Burden of Heart Failure. Card Fail Rev. 2017;3(1):7-11.

2. Allen LA, Stevenson LW, Grady KL, Goldstein NE, Matlock DD, Arnold RM, Cook NR, Felker GM, Francis GS, Hauptman PJ, Havranek EP, Krumholz HM, Mancini D, Riegel B, Spertus JA, Association AH, Research CoQoCaO, Nursing CoC, Cardiology CoC, Intervention CoCRa, Anesthesia CoCSa. Decision making in advanced heart failure: a scientific statement from the American Heart Association. Circulation. 2012;125(15):1928-52.

3. Fox K, Borer JS, Camm AJ, Danchin N, Ferrari R, Lopez Sendon JL, Steg PG, Tardif JC, Tavazzi L, Tendera M, Group HRW. Resting heart rate in cardiovascular disease. J Am Coll Cardiol. 2007;50(9):823-30.

4. Diaz A, Bourassa MG, Guertin MC, Tardif JC. Long-term prognostic value of resting heart rate in patients with suspected or proven coronary artery disease. Eur Heart J. 2005;26(10):967-74.

5. Fox K, Ford I, Steg PG, Tendera M, Robertson M, Ferrari R, Investigators B. Heart rate as a prognostic risk factor in patients with coronary artery disease and left-ventricular systolic dysfunction (BEAUTIFUL): a subgroup analysis of a randomised controlled trial. Lancet. 2008;372(9641):817-21.

6. Disegni E, Goldbourt U, Reicher-Reiss H, Kaplinsky E, Zion M, Boyko V, Behar S, SPRINT Study Group Secondary Prevention Reinfarction Israeli Nifedipine Trial. The predictive value of admission heart rate on mortality in patients with acute myocardial infarction. J Clin Epidemiol. 1995;48(10):1197-205.

7. Giannoglou GD, Chatzizisis YS, Zamboulis C, Parcharidis GE, Mikhailidis DP, Louridas GE. Elevated heart rate and atherosclerosis: an overview of the pathogenetic mechanisms. Int J Cardiol. 2008;126(3):302-12.

8. Rao K, Fisher ML, Robinson S, Shorofsky S, Gottlieb SS. Effect of chronic changes in heart rate on congestive heart failure. J Card Fail. 2007;13(4):269-74.

9. Castagno D, Skali H, Takeuchi M, Swedberg K, Yusuf S, Granger CB, Michelson EL, Pfeffer MA, McMurray JJ, Solomon SD, Investigators C. Association of heart rate and outcomes in a broad spectrum of patients with chronic heart failure: results from the CHARM (Candesartan in Heart Failure: Assessment of Reduction in Mortality and morbidity) program. J Am Coll Cardiol. 2012;59(20):1785-95.

10. von Lueder TG, Kotecha D, Atar D, Hopper I. Neurohormonal Blockade in Heart Failure. Card Fail Rev. 2017;3(1):19-24.

11. Swedberg K, Komajda M, Böhm M, Borer JS, Ford I, Dubost-Brama A, Lerebours G, Tavazzi L, Investigators S. Ivabradine and outcomes in chronic heart failure (SHIFT): a randomised placebo-controlled study. Lancet. 2010;376(9744):875-85.

12. Swedberg K, Komajda M, Böhm M, Borer J, Robertson M, Tavazzi L, Ford I, Investigators S. Effects on outcomes of heart rate reduction by ivabradine in patients with congestive heart failure: is there an influence of beta-blocker dose?: findings from the SHIFT (Systolic Heart failure treatment with the I(f) inhibitor ivabradine Trial) study. J Am Coll Cardiol. 2012;59(22):1938-45.

13. Ponikowski P, Voors AA, Anker SD, Bueno H, Cleland JGF, Coats AJS, Falk V, González-Juanatey JR, Harjola VP, Jankowska EA, Jessup M, Linde C, Nihoyannopoulos P, Parissis JT, Pieske B, Riley JP, Rosano GMC, Ruilope LM, Ruschitzka F, Rutten FH, van der Meer P, Group ESD. 2016 ESC Guidelines for the diagnosis and treatment of acute and chronic heart failure: The Task Force for the diagnosis and treatment of acute and chronic heart failure of the European Society of Cardiology (ESC) Developed with the special contribution of the Heart Failure Association (HFA) of the ESC. Eur Heart J. 2016:37(27):2129-200.

14. Hidalgo FJ, Anguita M, Castillo JC, Rodríguez S, Pardo L, Durán E, Sánchez $\mathrm{J}$, Ferreiro C, Pan M, Mesa D, Delgado M, Ruiz M. Effect of early treatment with ivabradine combined with beta-blockers versus beta-blockers alone in patients hospitalised with heart failure and reduced left ventricular 
ejection fraction (ETHIC-AHF): a randomised study. Int J Cardiol. 2016;217:7-11.

15. Cullington D, Goode KM, Zhang J, Cleland JG, Clark AL. Is heart rate important for patients with heart failure in atrial fibrillation? JACC Heart Fail. 2014;2(3):213-20.

16. Bui AL, Grau-Sepulveda MV, Hernandez AF, Peterson ED, Yancy CW, Bhatt DL, Fonarow GC. Admission heart rate and in-hospital outcomes in patients hospitalized for heart failure in sinus rhythm and in atrial fibrillation. Am Heart J. 2013:165(4):567-574.e6.

17. Abraham WT, Fonarow GC, Albert NM, Stough WG, Gheorghiade M, Greenberg BH, O'Connor CM, Sun JL, Yancy CW, Young JB, Coordinators O-Hla. Predictors of in-hospital mortality in patients hospitalized for heart failure: insights from the Organized Program to Initiate Lifesaving Treatment in Hospitalized Patients with Heart Failure (OPTIMIZE-HF). J Am Coll Cardiol. 2008:52(5):347-56.

18. Kajimoto K, Sato N, Keida T, Sakata Y, Asai K, Mizuno M, Takano T, registry iotADHFSA. Low admission heart rate is a marker rather than a mediato of increased in-hospital mortality for patients with acute heart failure syndromes in sinus rhythm. Int J Cardiol. 2014;171 (1):98-100.

19. Lourenço $P$, Ribeiro $A$, Cunha FM, Pintalhão M, Marques $P$, Cunha F, Silva $S$, Bettencourt P. Is there a heart rate paradox in acute heart failure? Int J Cardiol. 2016;203:409-14.

20. Takahama H, Yokoyama H, Kada A, Sekiguchi K, Fujino M, Funada A, Amaki M, Hasegawa T, Asakura M, Kanzaki H, Anzai T, Kitakaze M. Extent of heart rate reduction during hospitalization using beta-blockers, not the achieved heart rate itself at discharge, predicts the clinical outcome in patients with acute heart failure syndromes. J Cardiol. 2013;61 (1):58-64.

21. Alapati V, Tang F, Charlap E, Chan PS, Heidenreich PA, Jones PG, Spertus JA, Srinivas V, Kizer JR. Discharge heart rate after hospitalization for myocardial infarction and long-term mortality in 2 US registries. J Am Heart Assoc. 2019:8(3):e010855.

22. Rosa $A B$, Domingo PF, Francisco GS, Juan DJ, Rafael VP, Inés GO, Andreu FG, Jesús Á, Fernando WD, Jesús S, María Generosa CL, Juan CC, Francisco FA, Jose Ramón GJ, II) REdICrR. Prognostic value of discharge heart rate in acute heart failure patients: More relevant in atrial fibrillation? Int J Cardiol Heart Vasc. 2020;26:100444

23. McKee PA, Castelli WP, McNamara PM, Kannel WB. The natural history of congestive heart failure: the Framingham study. N Engl J Med. 1971;285(26):1441-6.

24. Levy WC, Mozaffarian D, Linker DT, Sutradhar SC, Anker SD, Cropp AB, Anand I, Maggioni A, Burton P, Sullivan MD, Pitt B, Poole-Wilson PA, Mann $\mathrm{DL}$, Packer $\mathrm{M}$. The seattle heart failure model: prediction of survival in heart failure. Circulation. 2006;113(11):1424-33.

25. O'Connor CM, Abraham WT, Albert NM, Clare R, Gattis Stough W, Gheorghiade M, Greenberg BH, Yancy CW, Young JB, Fonarow GC. Predictors of mortality after discharge in patients hospitalized with heart failure: an analysis from the Organized Program to Initiate Lifesaving Treatment in Hospitalized Patients with Heart Failure (OPTIMIZE-HF). Am Heart J. 2008;156(4):662-73.

26. O'Connor CM, Mentz RJ, Cotter G, Metra M, Cleland JG, Davison BA, Givertz MM, Mansoor GA, Ponikowski P, Teerlink JR, Voors AA, Fiuzat M,
Wojdyla D, Chiswell K, Massie BM. The PROTECT in-hospital risk model: 7-day outcome in patients hospitalized with acute heart failure and renal dysfunction. Eur J Heart Fail. 2012;14(6):605-12.

27. Lee DS, Stitt A, Austin PC, Stukel TA, Schull MJ, Chong A, Newton GE, Lee $J S$, Tu JV. Prediction of heart failure mortality in emergent care: a cohort study. Ann Intern Med. 2012;156(11):767-75.

28. Ishii S, Inomata T, Ikeda Y, Nabeta T, Iwamoto M, Watanabe I, Naruke T, Shinagawa $\mathrm{H}$, Koitabashi T, Nishii M, Takeuchi I, Izumi T. Clinical significance of heart rate during acute decompensated heart failure to predict left ventricular reverse remodeling and prognosis in response to therapies in nonischemic dilated cardiomyopathy. Heart Vessels. 2014;29(1):88-96.

29. Jensen MT, Kaiser C, Sandsten KE, Alber H, Wanitschek M, Iversen A, Jensen JS, Pedersen S, Soerensen R, Rickli H, Zurek M, Fahrni G, Bertel O, De Servi S, Erne P, Pfisterer M, Galatius S, investigators B-P. Heart rate at discharge and long-term prognosis following percutaneous coronary intervention in stable and acute coronary syndromes-results from the BASKET PROVE trial. Int J Cardiol. 2013;168(4):3802-6.

30. Laskey WK, Alomari I, Cox M, Schulte PJ, Zhao X, Hernandez AF, Heidenreich PA, Eapen ZJ, Yancy C, Bhatt DL, Fonarow GC. Heart rate at hospital discharge in patients with heart failure is associated with mortality and rehospitalization. J Am Heart Assoc. 2015. https://doi.org/10.1161/ JAHA.114.001626.

31. Anderson SG, Shoaib A, Myint PK, Cleland JG, Hardman SM, McDonagh TA, Dargie H, Keavney B, Garratt CJ, Mamas MA. Does rhythm matter in acute heart failure? An insight from the British Society for Heart Failure National Audit. Clin Res Cardiol. 2019;108(11):1276-86.

32. Kotecha D, Flather MD, Altman DG, Holmes J, Rosano G, Wikstrand J, Packer M, Coats AJS, Manzano L, Böhm M, van Veldhuisen DJ, Andersson B, Wedel H, von Lueder TG, Rigby AS, Hjalmarson Å, Kjekshus J, Cleland JGF, Group B-BiHFC. Heart rate and rhythm and the benefit of beta-blockers in patients with heart failure. J Am Coll Cardiol. 2017;69(24):2885-966.

33. Kanbay M, Afsar B, Siriopol D, Dincer N, Erden N, Yilmaz O, Sag AA, Kuwabara M, Cherney D, Rossignol P, Ortiz A, Covic A. Effect of uric acidlowering agents on cardiovascular outcome in patients with heart failure: a systematic review and meta-analysis of clinical studies. Angiology. 2020;71(4):315-23.

34. Givertz MM, Anstrom KJ, Redfield MM, Deswal A, Haddad H, Butler J, Tang WH, Dunlap ME, LeWinter MM, Mann DL, Felker GM, O'Connor CM, Goldsmith SR, Ofili EO, Saltzberg MT, Margulies KB, Cappola TP, Konstam MA, Semigran MJ, McNulty SE, Lee KL, Shah MR, Hernandez AF, Network NHFCR. Effects of xanthine oxidase inhibition in hyperuricemic heart failure patients: the xanthine oxidase inhibition for hyperuricemic heart failure patients (EXACT-HF) Study. Circulation. 2015;131(20):1763-71.

\section{Publisher's Note}

Springer Nature remains neutral with regard to jurisdictional claims in published maps and institutional affiliations.

\footnotetext{
Ready to submit your research? Choose BMC and benefit from:

- fast, convenient online submission

- thorough peer review by experienced researchers in your field

- rapid publication on acceptance

- support for research data, including large and complex data types

- gold Open Access which fosters wider collaboration and increased citations

- maximum visibility for your research: over $100 \mathrm{M}$ website views per year
}

At BMC, research is always in progress.

Learn more biomedcentral.com/submissions 